\section{Assessing the Economic Contributions and Benefits of Consumer Horticulture}

\author{
Lucy K. Bradley ${ }^{1,9}$, Bridget K. Behe ${ }^{2}$, Natalie R. Bumgarner ${ }^{3}$, \\ Charlotte D. Glen ${ }^{4}$, Joseph L. Donaldson ${ }^{5}$, Ellen M. Bauske ${ }^{6}$, \\ Sheri Dorn ${ }^{7}$, and Gail Langellotto ${ }^{8}$
}

AdDitional INDEX wORDs. gardening, landscape, value, financial, urban

Summary. Consumer horticulture $(\mathrm{CH})$ programming can result in outcomes and impacts at the individual level, such as money saved by reducing inputs, greater return on the landscape investment, healthier plants, and improved quality of life. It may also lead to community-level impacts that provide public value, such as water quality protection, water conservation, and protection of biodiversity. In addition to documenting such outcomes and impacts, it is important to quantify their economic value, connect the value to actions taken by extension audiences, and demonstrate to extension's stakeholders a return on investment. However, it is difficult to document the economic contributions of consumer horticulture and even more difficult to document the economic impact of consumer horticulture extension programs. $\mathrm{CH}$ reaches individuals and communities directly and indirectly through personal gardens and landscapes, indoor flowers and plants, school and community gardens, and horticulture therapy. The economic contributions and benefits of consumer horticulture are challenging to quantify, but can be evaluated using several different strategies, including measuring the consumer dollars spent and the economy driven by consumers' purchase of gardening supplies and landscape services. A second strategy is to examine the value of consumers' gardening actions on environmental ecosystem services that support soils and plants, provide food and raw materials, and regulate functions, such as pollination, storm water catchment, water quality preservation, green waste reduction, and wildlife habitat and diversity. A third strategy is to focus on cultural, social, and health system services, such as education, recreation, and therapy, that result in exercise, nutrition, health, and happiness. Using a combination of these strategies, workgroups of Tennessee extension professionals are balancing the feasibility of data collection with the usefulness of the data gathered by developing realistic and robust outcome indicators that will form the basis for local and statewide reporting.

$\mathrm{C}$ onsumer horticulture embraces a broad range of activities of interest and benefit to the public (Bauske et al., 2014), including, but not limited to, interior and exterior ornamental gardening, food gardening, and community gardening (Bauske et al., 2015). These activities affect the environment in many ways and are intimately intertwined with esthetic preference and human well-being (Bauske et al., 2015).

Extension specialists and agents engaging with $\mathrm{CH}$ stakeholders focus their educational and research efforts on activities and practices that impact consumers. Although $\mathrm{CH}$ specialists and educators may interact with a wide range of $\mathrm{CH}$ stakeholders, including the gardening public, green industry professionals, environmental organizations, public health agencies, institutional organizations, and businesses (Bradley et al., 2016), their educational programming generally focuses on gardeners and their interests. This focus on consumers, rather than the businesses that serve them, is different from the focus of many horticulture extension professionals who work directly on enhancing production or lowering crop or animal loss for agricultural business, including farms, nurseries, landscapers, and service industries.

Extension professionals, including state specialists, county faculty, educators, and volunteers, are operating within a university model of competitive funding and are receiving increasing pressure to justify their time and efforts in reaching this audience. Although $\mathrm{CH}$ may be the largest stakeholder audience in many extension agriculture programs, it can be underappreciated due to the complexity and difficulty of reporting the impact. Contacts reported must be augmented by higher-order metrics, such as knowledge gained, behavior changed, and economic impacts, because that is the standard for reporting in most other agricultural sectors, but these metrics must be clear and appropriate to obtain the necessary widespread adoption.

Hall and Hodges (2011) provided a useful framework for determining the value of $\mathrm{CH}$. They included many aspects of $\mathrm{CH}$ when they outlined the economic, environmental, and well-being benefits of what they referred to as "lifestyle horticulture."

The economic benefits of $\mathrm{CH}$ are substantial. Gardeners drive the purchase of an array of specialty crops and related products, services, and experiences. They influence wholesale nurseries, greenhouses, turfgrass producers, landscape designers, construction and maintenance firms, and wholesale and retail distribution firms, such as garden centers, farmers markets, community-supported agriculture, home stores, mass merchandisers with lawn/garden departments, brokers and rewholesale distribution centers, and allied trade suppliers of inputs to the industry. A recent estimate of the direct industry output (goods, materials, and services) for all sectors of the green industry in the United States was $\$ 136.44$ billion, and total output contributions (includes indirect/induced multiplier effects) were $\$ 196.07$ billion (Hodges et al., 2015). In 2013, the industry directly employed 1.6 million people in the United States, including 1.1 million jobs in landscaping services, 0.2 million in nursery and greenhouse and 0.2 million in lawn and garden supply stores (Hodges et al., 2015).

As noted by Hall and Dickson (2011) and Watson et al. (2007), the environmental benefits of $\mathrm{CH}$ are also substantial. Nutrient cycling, carbon sequestration, water and air purification, storm water mitigation, aquifer recharge, and moderating urban heat islands (Cameron et al., 2012; Nowak et al., 2006; Pataki et al., 2011) are all ways that $\mathrm{CH}$ systems directly contribute to environmental sustainability.

Systems and practices of $\mathrm{CH}$ also influence human health and well-being (Hall and Dickson, 2011). They encourage healthy eating habits (Langellotto and Gupta, 2012) and 
physical activity (Gunn et al., 2005; Hug et al., 2009; Humpel et al., 2002; Takano et al., 2002; Withers et al., 2006). Fresh food for families and individuals is provided by $\mathrm{CH}$ systems (home and community gardens). They impact the perception of safety (Brownlow, 2005; Herzog and Chernick, 2009) and help reduce mental fatigue and stress while increasing concentration and selfdiscipline (Kuo, 2001; Kuo and Sullivan, 200la, 2001b; Taylor et al., 2002). Also, CH systems reduce noise and satisfy our innate need for natural repose and beauty (Kaplan and Kaplan, 1989; Shearman, 2006).

Extension educational programs in the $\mathrm{CH}$ area help relate the benefits of improved landscapes (and how to install and maintain them properly), thus ensuring that citizens realize the full spectrum of these economic, environmental, and health benefits, but measuring this impact is a daunting task. Identifying the environmental and social impacts of $\mathrm{CH}$ is impeded by a lack of research that is scale and system-appropriate, and that considers the broad context of $\mathrm{CH}$ systems in urban, suburban, and rural landscapes. Hall and Hodges (2011) summarized the challenge, "How does one place an economic value on such nebulous but vital amenities

\section{This article is based on the presentations of the workshop "Yes Virginia, There Really Is an Economic Impact of Consumer Horticulture," held August 10, 2016, during the ASHS Annual Conference, Atlanta, GA, and sponsored by the Consumer Horticulture and Master Gardeners (CHMG) Working Group. \\ ${ }^{1}$ Department of Horticultural Science, North Caro- lina State University, Campus Box 7609, Kilgore Hall 128, 2721 Founders Drive, Raleigh, NC 27695 \\ ${ }^{2}$ Department of Horticulture, Michigan State Uni- versity, 1066 Bogue Street, East Lansing, MI 48824 \\ ${ }^{3}$ Plant Sciences Department, University of Tennessee, 2431 Joe Johnson Drive, 252 Ellington Plant Sci- ences, Knoxville, TN 37996 \\ ${ }^{4}$ Cooperative Extension, North Carolina State Uni- versity, 1192 US 64 West Business, Suite 400, Pitts- boro, NC 27312 nize Local Realities." Workshop participants included $\mathrm{CH}$ extension professionals, such as program co- ordinators, agents, and specialists, as well as other ASHS members con- nected to $\mathrm{CH}$, such as economists, department heads, and graduate students. \\ Considerations to quantify the economic contributions and benefits of consumer gardening}

${ }^{5}$ University of Tennessee, 4-H Youth Development/ Agricultural Leadership, Education and Communications, 212D Morgan Hall, Knoxville, TN 37996

${ }^{6}$ Center for Urban Agriculture, University of Georgia, 1109 Experiment Street, Griffin, GA 30223

${ }^{7}$ Department of Horticulture, University of Georgia, 1109 Experiment Street, Griffin, GA 30223

${ }^{8}$ Department of Horticulture, Oregon State University, 4017 ALS Building, Corvallis, OR 97331

${ }^{9}$ Corresponding author. E-mail: Lucy_Bradley@ncsu. edu.

doi: 10.21273/HORTTECH03784-17 that enhance the quality of life so dramatically?"

On 10 Aug. 2016 at the annual conference of the American Society for Horticultural Science in Atlanta, $\mathrm{GA}$, the $\mathrm{CH}$ and Master Gardeners Professional Interest Group hosted a workshop with the objective of exploring the challenges and potential solutions $\mathrm{CH}$ researchers and extension educators face when attempting to assess the economic impact of their work.

The workshop addressed several aspects of measuring the contributions of $\mathrm{CH}$ extension programming. Recognizing that understanding the consumer is an important first step in measuring the economic benefits of extension educational programs, Dr. Bridget Behe presented "Considerations to Quantify the Economic Contributions and Benefits of Consumer Gardening." To present potential examples for monetizing the many benefits of $\mathrm{CH}$, such as health, well-being, and biodiversity, Ms. Charlotte Glen reviewed the current state of research in "Tools for Evaluating the Economic Contributions and Benefits of extension $\mathrm{CH}$ Education Programs." Finally, Dr. Natalie Bumgarner described a process for creating evaluation methodology that can be aggregated statewide and yet remain meaningful locally, entitled "Designing Evaluation Metrics that Meet State Needs and Recog-

There are three key factors to consider when assessing the purchasing power of participants in $\mathrm{CH}$ educational programs: consumer choice, product evaluation, and consumption methods.

Consumer choice is influenced by personal, situational, social, and psychological influences (Kotler and Keller, 2009). Personal influences include age, life stage, vocation, self-identity, personality, lifestyle, and affluence. Situational influences encompass time, shopping environment, and context. Social influences comprised cultural and subcultural, reference groups, opinion leaders, social class, family, and gender roles. Psychological influences on consumer behavior are shaped by attitudes, beliefs, perception, motivation, and learning.

The second factor to consider when quantifying the economic contribution of $\mathrm{CH}$ is product evaluation, including product life cycle and product adoption curve. Product life cycles are highly predictable (Kotler and Keller, 2009). However, one must understand current consumer attitudes and behaviors to capitalize on the product life cycle.

Miller (2016) reported results from a survey to identify consumer perceptions of gardening and concluded that the act of gardening has mostly positive impressions, although there are significant negatives (it is dirty, it is hard work). Consumers have distinct ideas of the type of person who gardens-and it is often a limiting viewpoint (I am not a "gardener"). Consumers lack a sense of control when it comes to gardening. They repeatedly used the terms "luck" and "risk" when describing gardening. Concern over food attributes, including the source and production method, has repositioned the spotlight on edible horticulture. There is great interest in eating locally (farmer's markets and restaurants) and some interest in growing one's own food (herbs and vegetables). Consumer focus on the environment has influenced the industry to be aware of environmental impacts, including carbon sequestration, global warming, water quality and quantity, and pollinator health. Garden centers are the third-most popular place to buy plants, after big box stores and grocery stores.

Involvement and expertise are constructs that affect consumer attitudes and knowledge. Highly involved consumers are more keenly interested in a product, brand, or product line (Behe et al., 2013). Product experts know more and make decisions differently compared with those with less expertise.

The third factor to consider when considering the economic 
contribution of $\mathrm{CH}$ is consumption methods, including gardeningrelated purchases and participation in gardening activities. The horticulture industry is related to the housing market, and U.S. home ownership has declined steadily since 2009 (U.S. Census Bureau, 2017). In addition, in $2014,32 \%$ of 18 to 34-year olds lived with their parents (Fry, 2016). This raises concern over traditional sales volumes and expansion of market. Although homeowners are the predominant consumer of the green industry, renters do participate in gardening, but differently (Behe, 2006). Renters purchase less than owners and desire smaller cultivars in smaller quantities compared with the average homeowner. In addition, generational cohorts vary in where they live, what matters to them, how they play, where they get their news, and whom they trust (Behe et al., 2016).

The economic contributions of $\mathrm{CH}$ may be measured both on the production and the consumption sides. For example, in production, the product life cycle and the product adoption curve provide measurable data. Gardening-related purchases and participation are both measures of consumer consumption and impact. For example, Butterfield and Baldwin (2015) reported that 80 million U.S. households (96\%) purchased lawn and garden products in $2014,26 \%$ of households purchased lawn care and landscape services in 2014 (15.9\% lawn care, $8.4 \%$ landscape maintenance, $1.7 \%$ landscape design, and 3.3\% landscape installation), and 84 million households participated in one or more types of do-it-yourself, indoor or outdoor lawn and garden activities in 2014.

Total lawn and garden retail sales in 2014 was $\$ 26.64$ billion. The number of households participating in gardening and landscaping activities in 2014 was one million more than the previous 5-year average. However, the $\$ 317$ average household expenditure was 7\% less than the previous 5-year average. In addition to the economic contributions associated with the purchasing power of gardeners, there is also an economic contribution associated with their gardening and landscaping efforts.

\section{Tools for evaluating the economic contributions and benefits of $\mathrm{CH}$}

Extension programming in residential landscape sustainability can result in outcomes and impacts both at the individual level, such as money saved, greater return on the landscape investment, healthier plants, and a reduced need for inputs; and at the community level, such as increased public value for water and air quality protection, water conservation, and protection of biodiversity (Cameron et al., 2012; Hall et al., 2017; Pataki et al., 2011). However, measuring the economic benefits of extension educational programming remains a challenge. As demand for programming accountability increases, it becomes critical to quantify impacts with dollar values and show stakeholders a return on investment can be accomplished by monetizing the differences that programming makes in people's lives.

Economic benefit reporting frequently focuses on increased participant income from sales or wages, as well as reduced cost resulting from more efficient use of fertilizer, water (Reid and Oki, 2008; St. Hilaire et al., 2008), and energy (Parker, 1983). These studies measured the value of the impact on participants rather than the value of public, social, and environmental impacts of $\mathrm{CH}$. Methods for quantifying the economic value of many benefits of $\mathrm{CH}$ (such as esthetic value, happiness, environmental literacy, and ecosystem services) have not been identified, while methods for quantifying others (reduction in storm water runoff, reduced need for water treatment, reduced gray infrastructure needs, carbon dioxide sequestration, and air quality improvement) exist, but are challenging to adapt to program outcomes within an individual residential setting.

One strategy for assigning an economic value to these benefits involves determining a "willingness to pay," (National Research Council, 2005 ), which is a valuation strategy that has been applied to a range of agricultural and environmental practices, including the prevention of aquatic nuisance species (Blaine and Lichtkoppler, 2016), green space and farmland conservation easements (Blaine et al., 2003), and to produce grown using organic techniques or integrated pest management (Zehnder et al., 2003). Willingness to pay has also been used to assess potential $\mathrm{CH}$ benefits. Helfand et al. (2006) found that residents of southeast Michigan were willing to pay more for well-designed landscapes dominated by native plants compared with lawn-dominated landscapes. Similar results were realized in a multistate study that showed landscape attributes, particularly design sophistication, increased home values an average of $9 \%$ over homes without landscaping (Behe et al., 2005; Niemiera, 2009).

Asking consumers to directly state their willingness to pay for a specific good or service based on a hypothetical scenario, known as contingent valuation, is a controversial strategy for documenting economic contributions because respondents may not provide entirely accurate answers because of their desire to influence survey results (Carson, 2000; King and Mazzotta, 2000). Another strategy is to estimate how a $\mathrm{CH}$ item affects the market price of another item, such as the impact of tree presence and size on housing price (Anderson and Cordell, 1988; Holmes et al., 2006). The presence of tree cover in a landscape has been found to not only increase the value of the property on which the tree is located, but also to positively influence the value of properties located within $250 \mathrm{~m}(820.2 \mathrm{ft})$ (Sander et al., 2010).

Time is another dimension to the challenge of communicating the value of plants, landscaping, and extension's related educational programming. Many $\mathrm{CH}$ impacts occur years after the initial actions responsible for the benefit. For example, the shade created by a full-grown tree is the direct result of planting a seed many years earlier. The impacts of horticultural practices and choices occur over time and can best be communicated as medium- and long-term outcomes.

There are several tools available to assist in assessing the economic contribution of $\mathrm{CH}$. The most extensive economic data currently available relative to sustainable residential landscapes are documented economic impact of trees, such as energy savings, storm water management, increased property values, and air quality improvement (McPherson, 
2007; McPherson et al., 2011). There are a variety of digital tools available, including Community Tree Guides (U.S. Forest Service, 2006), i-Trees (U.S. Forest Service, 2017), and the National Tree Benefit Calculator (Casey Trees and Davey Trees, 2017). The U.S. Department of Agriculture (USDA) Forest Service produces Community Tree Guides for each of the 16 climate zones. According to the Piedmont Community Tree Guide (McPherson et al., 2006), the average dollar value of the net benefits resulting from energy savings, carbon dioxide reduction, air quality impacts, storm water benefits, and increased property value per tree per year for a 40 -year period (assumes $55 \%$ survival rate) are $\$ 7$ to $\$ 18$ for small trees, $\$ 23$ to $\$ 35$ for medium trees, $\$ 83$ to $\$ 92$ for large trees, and $\$ 31$ to $\$ 44$ for conifers. i-Trees, the state-of-the-art, peer-reviewed software suite from the USDA Forest Service, estimates benefits based on tree location, species, size, and condition. It factors in benefits from greenhouse gas mitigation, air quality improvements, storm water interception, carbon sequestration, and energy savings.

Another tool for calculating economic value of $\mathrm{CH}$, specifically green infrastructure practices, is The Value of Green Infrastructure: A Guide to Recognizing its Economic, Environmental, and Social Benefits (Center for Neighborhood Technology, 2010). This guide includes an illustrative matrix that summarizes the benefits of $\mathrm{CH}$ practices, such as rain gardens, tree planting, and water harvesting. For example, the benefits of rain gardens (bioretention) for which economic values can be calculated include reduced storm water runoff, reduced atmospheric carbon dioxide, and improved air quality. Rain garden benefits that are less easily monetized include improved habitat, improved community livability, and reduced urban heat island effect.

Ecosystem Valuation (King and Mazzotta, 2000) is a model used to quantify the beneficial ways that ecosystems affect people. Similarly, EnviroAtlas (U.S. Environmental Protection Agency, 2016) provides interactive resources for exploring critical ecosystem goods and services, including human health and well-being. EnviroAtlas allows users to analyze diverse information to predict the potential impacts of various actions.

In some cases, the benefit can be quantified, but documenting the impact for specific practices is still difficult (Jaffe, 2010; Vandermeulen et al., 2011). For example, the value of pollination services to agriculture is known, but research is needed to quantify the impact of a pollinator garden in a home landscape on pollination services. As another example, the benefits of green infrastructure have been monetized for commercial level development, but not the home landscape.

Other impacts, such as cultural ecosystem services, such as health and well-being, biodiversity, and wildlife habitat, are not widely monetized. Additional studies are needed to quantify economic benefits of specific practices and to monetize other known benefits derived from $\mathrm{CH}$ practices. Once economic impacts of $\mathrm{CH}$ are documented, it is essential to tie extension programming outcomes to those economic impacts.

\section{Tennessee extension: A case study in designing evaluation metrics that meet state needs and recognize local realities}

It is important to establish the value of $\mathrm{CH}$ contributions on the marketplace and the environment, but extension practitioners must also quantify the role of education in providing value to the $\mathrm{CH}$ stakeholder and the horticulture industry. Direct education in the form of workshops and presentations, as well as help desks and one-on-one problem solving of landscape and garden issues, are each forms of $\mathrm{CH}$ outreach. It also includes mass media, such as television, radio, and a range of print and digital media (indirect contacts); demonstration gardens; tours; and a variety of other techniques. As noted previously, education through these outlets addresses long-term issues, including food production and security, human health, and environmental stewardship, as well as shortterm decisions that include lawn and garden purchases and weed, pest, and disease management issues.

There are three key challenges to reporting the economic benefits of extension $\mathrm{CH}$ education. First is the size and diffuse nature of our outreach and education efforts, which span the entire lawn and garden spectrum. Second is the diversity and magnitude of both the audience (including a majority of individuals and communities) and our educators (including thousands of professionals and volunteers). The third challenge is in focusing on the end user rather than on production or distribution, which are more easily quantified.

Even with challenges, reporting is essential, and detailing stakeholder contacts is routine. Currently, extension personnel working in $\mathrm{CH}$ often report compelling data that describes people reached. For instance, in Tennessee in 2016, residential and $\mathrm{CH}$ outreach directly reached 135,905 citizens and indirectly reached another $10,148,251$ citizens. These educational efforts were conducted by $\approx 80$ extension personnel and nearly 2400 volunteers (University of Tennessee, unpublished data). The number of Extension Master Gardener volunteer (EMGV) hours, number of volunteers, and total dollar value of volunteer service are reported as well. These numbers compare favorably to some of the state's important production agriculture areas. For instance, beef programming reached 158,823 contacts directly and $6,431,563$ indirectly, whereas row crop-corn contacts were reported as 10,588 direct and 91,330 indirect contacts.

With extension's public funds also comes a responsibility to show a return on investment across a number of mandated metrics. In Tennessee specifically, extension uses four key types of evaluation data to critique programs: 1) economic impact, 2 ) educational impact, 3 ) area of need, and 4) number of people reached through direct and indirect contacts. These numbers are reported to USDA National Institute of Food and Agriculture through the Plan of Work and Accountability system, TN lawmakers (consistent with the Governmental Accountability Act of 2013), and local government.

To standardize educational impacts and aggregate efforts from personnel across the state, TN Extension has a system of outcome indicators housed within the statewide extension evaluation and reporting system, SUPER. These indicators are 
completed by county agents and educators throughout the year and aggregated into end-of-year statewide reports. However, the use of current indicators creates challenges for Tennessee personnel in $\mathrm{CH}$. An example of an educational impact assessed by a current outcome indicator is included below (Donaldson, 2006; University of Tennessee, unpublished data): " 205 of 674 participants plan to use the two-step method around the home for managing fire ants."

An educational impact such as this clearly addresses user outcomes, but presents challenges in delivering educational and/or economic data. For county extension personnel, the challenge is that this indicator gathers data on an extremely narrow topic that may be quite a small percentage of yearly programming. Agents select indicators using a planning process that encourages them to focus reporting on areas of highest priority and frequency. Therefore, narrow indicators are less likely to be used by agents. On a state reporting level, these types of indicators lead to underreporting of efforts and do not enable accurate educational impact assessment or economic valuation of the change in behavior resulting from the extension educational program.

To address these challenges, $\mathrm{TN}$ Extension workgroups (University of Tennessee, n.d.) were charged with revising the statewide outcome indicators to achieve two goals: 1) evaluation metrics need to be driven by state reporting needs, but recognize that county program realities limit the number of indicators agents must report and 2) metrics must be written collaboratively by groups of agents and specialists to be current and focus on critical educational programming while laying the foundation for describing economic contributions.

These directives have been addressed with a two-step process. First, workgroups collaborate to generate and categorize outcome indicators by topic. The goal is to reduce the number of indicators in content areas and ensure that broad indicators address current educational programming and cover a large percentage of training topics. Each workgroup is limited to developing two outcome indicators. Then, as the second step, it is proposed that consistent evaluations be developed for agents to collect accurate data by county, which can then be aggregated into detailed reports to quantify economic contributions for specific programs in specific counties, regions, and/or the entire state.

In the area of residential and consumer horticulture, three workgroups (including EMGVs, home fruit and vegetable production, and sustainable landscapes) have developed new outcome indicators. Each topic area will have two broad outcome indicators that agents will report on each year that should cover a large percentage of the $\mathrm{CH}$ outreach statewide. The goal of these indicators is to address the challenges of diverse programming delivered by a large number of extension personnel and volunteers. Table 1 provides sample impact statements for fruit and vegetable production and sustainable landscapes (University of Tennessee, unpublished data). This first step allows agents to track the number of participants, information gained, and behaviors changed and will address the issue of statewide underrepresentation of $\mathrm{CH}$ efforts.

The second step is to use more detailed evaluations and stakeholder follow-up surveys to describe purchases, food grown, or environmental outcomes directly impacted. This detailed information will not be gathered at every event in every county, but will instead focus on specific programs and locations to create a strong dataset. Data gathered from detailed instruments will provide an effective strategy for valuing $\mathrm{CH}$ contributions without needing to complete detailed surveys for every future educational program and stakeholder. Currently, the $\mathrm{CH}$ workgroups are facilitating cohesive use of the new outcome indicators. Developing more detailed

Table 1. Outcome indicators developed collaboratively by Tennessee Extension agents and specialists to collect consumer horticulture extension activities impacts.

\begin{tabular}{|c|c|c|}
\hline Workgroup content area & Home fruit and vegetable & Sustainable landscapes \\
\hline Behavioral changes & $\begin{array}{l}\text { participants stated that they plan to } \\
\text { implement this information on crop, } \\
\text { cultivar, and site selection; soil and fertility } \\
\text { management; cultural practices; plant } \\
\text { management practices; pest and disease } \\
\text { identification; integrated pest } \\
\text { management practices; or proper harvest } \\
\text { and handling to improve their home fruit } \\
\text { and vegetable production within the next } \\
\text { year. }\end{array}$ & $\begin{array}{l}\text { As a result of participation in extension } \\
\text { programming __ residents have } \\
\text { implemented conservation landscape } \\
\text { practices, plant selections, or sustainable } \\
\text { stewardship practices. }\end{array}$ \\
\hline
\end{tabular}


evaluations that will enable economic valuation has not been completed at this time.

Some of these topics are currently supported by published data that would enable the reporting of economic impact. Metrics exist for areas of frequent extension outreach, including consumer value of quality in home landscapes (Behe et al., 2005) and home garden food production values for specific regions (Algert et al., 2016; CoDyre et al., 2015). Other indicators may not yet have these research foundations. In these cases, future research will be required to enable $\mathrm{CH}$ practitioners to clearly describe the role of extension in impacting demand in the horticulture industry.

Ultimately, the goal is that these efforts will enable agents, educators, and specialists to communicate the value of consumer's reduced costs, increased income and productivity, and nonmarket benefits that result from actions taken after participation in extension's educational outreach or programming in a similar manner as reported by other agriculture sectors. Once the tools to adequately measure and quantify the economic, environmental, and social benefits of $\mathrm{CH}$ from a monetary standpoint are developed, they will be added to the outcome indicators. It will be an iterative process, but one that is well worth the effort because of the size of our audience and outreach impact potential.

\section{Conclusion}

$\mathrm{CH}$ clientele differ from the clientele of many of our extension colleagues. Many extension educators in agriculture work with businesses or services providers, including farmers, nurserymen, and landscapers. Often the goal of their educational programs is to increase efficiency, yield, or reduce loss, and these factors all have an economic benefit that can be evaluated with relative ease. Although consumers purchase goods and services that drive consumption and urban agricultural industries, the goal of $\mathrm{CH}$ education is neither to increase nor decrease consumption, but rather to increase gardening success and the associated economic, environmental, and well-being benefits.

$\mathrm{CH}$ education can and certainly does have an economic benefit. It can influence and expand consumption of goods and services by increasing the consumer's success in gardening. It can promote gardening by increasing the knowledge of environmental and well-being benefits. Extension educators can also play important roles in reaching out to new audiences and empowering new gardeners, expanding the pool of consumers. However, these benefits cannot be measured directly by the educators.

With the possible exception of trees, the environmental benefits of gardening have not been fully explored, let alone monetized. Recent work suggests that we have only begun to identify potential environmental benefits. In addition to the impact of $\mathrm{CH}$ on birds and other urban wildlife, landscapes practices may prove critical in sustaining pollinator population. Populations of managed bees have significantly declined (VanEngelsdorp et al., 2007). Several studies found exceptionally abundant and rich pollinator communities in $\mathrm{CH}$ systems (Hall et al., 2017).

$\mathrm{CH}$ educational activities have economic, environmental, and wellbeing benefits with short-, medium-, and long-term values and impacts. Articulating medium- and long-term benefits and communicating them is a daunting challenge.

The metrics proposed by Dr. Bumgarner suggest one possible path forward: collecting data that meet state needs and recognize local realities. Another possible next step will be to develop a calculator that would estimate economic, environmental, and health impacts based on participant report of behavior change and standardized impact data. Ultimately, it may be possible to monetize more of the economic, environmental, and health aspects of $\mathrm{CH}$ education; however, nonmonetized benefits are benefits nonetheless.

Resources for $\mathrm{CH}$ educational programs and research to identify and develop quantitative tools for measuring program impacts as well as targeted resources for using those tools to document $\mathrm{CH}$ impacts are all needed to move the field forward.

\section{Literature cited}

Algert, S., G.A. Baaumeur, L.O. Diekmann, L. Gray, and D. Ortiz. 2016. Vegetable output, cost savings, and nutritional value of low-income families' home gardens in San Jose, CA. J. Hunger Environ. Nutr. 11 (3):328-336.

Anderson, L.M. and H.K. Cordell. 1988. Influence of trees on residential property values in Athens, Georgia (USA) - A survey based on actual sales prices. Landsc. Urban Plan. 15(1-2):153-164.

Bauske, E.M., G.R. Bachman, T. Bewick, L.K. Bradley, D. Close, R. Durham, and M.H. Meyer. 2015. The case for a national strategic plan for consumer horticulture research, education, and extension. HortTechnology 25:477-479.

Bauske, E.M., G.R. Bachman, L.K. Bradley, A. Stoven O'Connor, and P.J. Bennett. 2014. Consumer horticulture outreach: Communication challenges and solutions. HortTechnology 24:266-269.

Behe, B.K. 2006. Comparison of gardening activities and purchases of homeowners and renters. J. Environ. Hort. 24 (4):217-220.

Behe, B., J. Hardy, S. Barton, J. Brooker, R.T. Fernandez, C.R. Hall, J. Hicks, R. Hinson, P.R. Knight, R. McNeil, T.J. Page, D.B. Rowe, C.D. Safley, and R. Schutzki. 2005. Landscape plant material, size, and design sophistication increase perceived home value. J. Environ. Hort. 23(3):127-133.

Behe, B.K. 2006. Comparison of gardening activities and purchases of homeowners and renters. J. Environ. Hort. 24 (4):217-220.

Behe, B.K., P.T. Huddleston, and L. Sage. 2016. Age cohort influences brand recognition, awareness, and likelihood to buy vegetable and herb transplants. HortScience 51:145-151.

Behe, B.K., J. Zhao, L. Sage, P.T. Huddleston, and S. Minahan. 2013. Display signs and involvement: The visual path to purchase intention. Intl. Rev. Retail Distrib. Consum. Res. 23 (5):511-522.

Blaine, T.W. and F.R. Lichtkoppler. 2016. Factors affecting stakeholders' willingness to pay to prevent the spread of aquatic nuisance species. J. Ext.54(6) 6FEA524 June 2017. <https://www.joe. org/joe/2016december/a5.php>.

Blaine, T.W., F.R. Lichtkoppler, and R. Stanbro. 2003. An assessment of residents' willingness to pay for green space and farmland preservation conservation easements using the contingent valuation method (CVM). J. Ext.4l(4)4FEA324 June 2017. <https://www.joe.org/joe/ 2003august/a3.php $>$.

Bradley, L.K., E.M. Bauske, T.A. Bewick, J.R. Clark, R.E. Durham, G. Langellotto, 
M.H. Meyer, M. Pooler, and S. Dorn. 2016. Developing a national strategic plan for consumer horticulture. HortTechnology 26:372-378.

Brownlow, A. 2005. A geography of men's fear. Geoforum 36(5):581-592.

Butterfield, B. and I. Baldwin. 2015. National gardening survey - 2015 edition. Natl. Gardening Assn., Williston, VT.

Cameron, R.W.F., T. Blanuša, J.E. Taylor, A. Salisbury, A.J. Halstead, B. Henricot, and K. Thompson. 2012. The domestic garden - Its contribution to urban green infrastructure. Urban For. Urban Green. 11(2):129-137.

Carson, R. 2000. Contingent valuation: A user's guide. Environ. Sci. Technol. 34 (8):413-1417.

Casey Trees and Davey Trees. 2017. National tree benefits calculator. 24 June 2017. <http://www.treebenefits.com/ calculator $>$.

Center for Neighborhood Technology. 2010. The value of green infrastructure: A guide to recognizing its economic, environmental, and social benefits. 24 June 2017. <http://www.cnt.org/sites/ default/files/publications/CNT_Valueof-Green-Infrastructure.pdf $>$.

CoDyre, M., E.D.G. Fraser, and K. Landman. 2015. How does your garden grow? An empirical evaluation of the costs and potential of urban gardening. Urban For. Urban Green. 14(1):72-79.

Donaldson, J.L. 2006. SUPER brochure. 24 June 2017. <https://extension. tennessee.edu/eesd/Documents / SUPER/SUPERBrochure.pdf>.

Fry, R. 2016. For first time in modern era, living with parents edges out other living arrangements for 18-to-34-year-olds. Pew Res. Ctr., Washington, DC.

Gunn, S.M., A.G. Brooks, R.T. Withers, C.J. Gore, J.L. Plummer, and J. Cormack. 2005. The energy cost of household and garden activities in 55- to 65-year-old males. Eur. J. Appl. Physiol. 94(4):476486.

Hall, C.R. and M.W. Dickson. 2011. Economic, environmental, and health/ well-being benefits associated with green industry products and services: A review. J. Environ. Hort. 29(2):96-103.

Hall, C.R. and A.W. Hodges. 2011. Economic, environmental and well-being benefits of lifestyle horticulture. Chron. Hort. 51(4):5-8.

Hall, D.M., G.R. Camilo, R.K. Tonietto, J. Ollerton, K. Ahrne, M. Arduser, J.S. Ascher, K.C.R. Baldock, R.E. Fowler,
G.W. Frankie, D. Goulson, B. Gunnarsson, M.E. Hanley, J.I. Jackson, G. Langellotto, D. Lowenstein, E.S. Minor, S.M. Philpott, S.G. Potts, M.H. Sirohi, E.M. Spevak, G. Stone, and C.G. Threlfall. 2017. The city as a refuge for insect pollinators: Conservation for the city. Conserv. Biol. 31 (1):24-29.

Helfand, G.E., J.S. Park, J.I. Nassauer, and S. Kosek. 2006. The economics of native plants in residential landscape designs. Landsc. Urban Plan. 78(3):229240 .

Herzog, T.R. and K.K. Chernick. 2009. Tranquility and danger in urban and natural settings. J. Environ. Psychol. 20 (1):29-39.

Hodges, A.W., C.R. Hall, M.A. Palma, and H. Khachatryan. 2015. Economic contributions of the green industry in the United States in 2013. HortTechnology 25:805-814.

Holmes, T.P., E.A. Murphy, and K.P. Bell. 2006. Exotic forest insects and residential property values. Agr. Resource Econ. Rev. 35(1):155-166.

Hug, S.M., T. Hartig, R. Hansmann, K. Seeland, and R. Hornung. 2009. Restorative qualities of indoor and outdoor exercise settings as predictors of exercise frequency. Health Place 15(4):971-980.

Humpel, N., N. Owen, and E. Leslie. 2002. Environmental factors associated with adults' participation in physical activity: A review. Amer. J. Prev. Med. 22 (3):188-199.

Jaffe, M. 2010. Environmental reviews and case studies: Reflections on green infrastructure economics. Environ. Pract. 12(4):357-365.

Kaplan, R. and S. Kaplan. 1989. The experience of nature: A psychological perspective. Cambridge Univ. Press, Cambridge, England.

King, D.M. and M.J. Mazzotta. 2000. Ecosystem valuation. 24 June 2017. <http:/www.ecosystemvaluation.org $>$.

Kotler, P. and K. Keller. 2009. Marketing management. 13th ed. Pearson Educ., London, England.

Kuo, F.E. 2001. Coping with poverty: Impacts of environment and attention in the inner city. Environ. Behav. 33 (1):5-34.

Kuo, F.E. and W.C. Sullivan. 2001a. Aggression and violence in the inner city: Effects of environment via mental fatigue. Environ. Behav. 33(4):543-571.

Kuo, F.E. and W.C. Sullivan. 2001b. Environment and crime in the inner city:
Does vegetation reduce crime? Environ. Behav. 33(3):343-367.

Langellotto, G.A. and A. Gupta. 2012. Gardening increases vegetable consumption in school-aged children: A meta-analytical synthesis. HortTechnology 22:430-445.

Miller, C. 2016. Help nature-loving gardening-skeptic consumers fall in love with plants. 24 June 2017. <http://www. greenhousegrower.com/retailing/helpnature-loving-gardening-skepticconsumers-fall-in-love-with-plants $>$.

McPherson, E.G. 2007. Benefit-based tree valuation. Arboricult. Urban For. 33 (1):1-11.

McPherson, E.G., J.R. Simpson, P.J. Peper, S.L. Gardner, K.E. Vargas, S.E. Maco, and Q. Xiao. 2006. Community tree guide: Benefits, costs, and strategic planting. 24 June 2017. <https://www. fs.fed.us/psw/publications/documents/ psw_gtr200/psw_gtr200guide.pdf $>$.

McPherson, E.G., J.R. Simpson, Q. Xiaob, and C. Wub. 2011. Million trees Los Angeles canopy cover and benefit assessment. Landsc. Urban Plan. 99 (1):40-50.

National Research Council. 2005. The meaning of value and use of economic valuation in the environmental policy decision-making process. Natl. Academies Press, Washington, DC.

Niemiera, A.X. 2009. The effect of landscape plants on perceived home value. Virginia Coop. Ext. Publ. 426-087. 24 June 2017. <https://www.pubs.ext.vt. edu/426/426-087/426-087.html >.

Nowak, D.J., D.E. Crane, and J.C. Stevens. 2006. Air pollution removal by urban trees and shrubs in the United States. Urban For. Urban Green. 4 (1):5-123.

Parker, J.H. 1983. Landscaping to reduce the energy used in cooling buildings. J. For. 81(2):82-105.

Pataki, D.E., M.M. Carreiro, J. Cherrier, N.E. Grulke, V. Jennings, S. Pincetl, R. V. Pouyat, T.H. Whitlow, and W.C. Zipperer. 2011. Coupling biogeochemical cycles in urban environments: Ecosystem services, green solutions, and misconceptions. Front. Ecol. Environ 9 (1):27-36.

Reid, S. and L. Oki. 2008. Field trials identify more native plants suited to urban landscaping. Calif. Agr. 62(3):97-104.

Sander, H., S. Polasky, and R.G. Haight. 2010. The value of urban tree cover: A hedonic property price model in Ramsey and Dakota counties, Minnesota, USA. Ecol. Econ. 69(8):1646-1656. 
Shearman, R.C. 2006. Fifty years of splendor in the grass. Crop Sci. 46 (5):2218-2229.

St. Hilaire, R.S., M.A. Arnold, D.C. Wilkerson, D.A. Devitt, B.H. Hurd, B.J. Lesikar, and D.R. Pittenger. 2008. Efficient water use in residential urban landscapes. HortScience 43:2081-2092.

Takano, T., K. Nakamura, and M. Watanabe. 2002. Urban residential environments and senior citizens' longevity in megacity areas: The importance of walkable green spaces. J. Epidemiol. Community Health 56(12):913-918.

Taylor, A.F., F.E. Kuo, and W.C. Sullivan. 2002. Views of nature and self-discipline: Evidence from inner city children. J. Environ. Psychol. 22(1):49-63.

University of Tennessee. n.d. Tennessee extension strategic business plan. 24 June 2017. <https://extension.tennessee.
edu/Documents /ANRCED-StrategicBusiness-Plan.pdf $>$.

U.S. Census Bureau. 2017. Quarterly residential vancancies and home ownership. 24 June 2017. <https://www. census.gov/housing/hvs/files/ currenthvspress.pdf>.

U.S. Environmental Protection Agency. 2016. EnviroAtlas. 24 June 2017. <https://www.epa.gov/enviroatlas>.

U.S. Forest Service. 2006. Community tree guides. 24 June 2017. <https:// www.fs.fed.us/psw/topics/urban_ forestry/products/tree_guides.shtml>.

U.S. Forest Service. 2017. i-Tree: Tools for assessing and managing forests and community trees. 24 June 2017. <https://www.itreetools.org/ resources/index.php>.

Vandermeulen, V., A. Verspecht, B. Vermeire, G. Van Huylenbroeck, and X. Gellynck. 2011. The use of economic valuation to create public support for green infrastructure investments in urban areas. Landsc. Urban Plan. 103(2):198206.

VanEngelsdorp, D., R.M. Underwood, D. Caron, and J. Hayes. Jr. 2007. An estimate of managed colony losses in the winter of 2006-7: A report commissioned by the Apiary Inspectors of America. Amer. Bee J. 147(7):599-603.

Watson, P., J. Wilson, D. Thilmany, and S. Winter. 2007. Determining economic contributions and impacts: What is the difference and why do we care? J. Regional Analysis Policy 37(2):1-15.

Withers, R.T., A.G. Brooks, S.M. Gunn, J.L. Plummer, C.J. Gore, and J. Cormack. 2006. Self-selected exercise intensity during household/garden activities and walking in 55 to 65-year-old females. Eur. J. Appl. Physiol. 97(4):494-504.

Zehnder, G., C. Hope, H. Hill, L. Hoyle, and J.H. Blake. 2003. An assessment of consumer preferences for IPM- and organically grown produce. J. Ext.4l(2) 2 RIB $3<$ https://www.joe.org/joe/ 2003april/rb3.php>. 